Vol.45, n. 4 : pp. 445-449, December 2002

ISSN 1516-8913 Printed in Brazil

BRAZILIAN ARCHIVES OF BIOLOGY AND TECHNOLOGY

AN INTERNATIONAL JOURNAL

\title{
Isolation of Rhodocyclus gelatinosus from Poultry Slaughterhouse Wastewater
}

\author{
Elisa Helena Giglio Ponsano ${ }^{1 *}$, Pedro Magalhães Lacava ${ }^{2}$ and Marcos Franke Pinto ${ }^{1}$ \\ ${ }^{1}$ Departamento de Apoio, Produção e Saúde Animal; Curso de Medicina Veterinária; Universidade Estadual \\ Paulista; C. P. 341; 16050-680; Araçatuba - SP - Brazil. ${ }^{2}$ Departamento de Bioquímica; Instituto de Quimica; \\ Universidade Estadual Paulista; C. P. 355; 14801-970; Araraquara - SP - Brazil
}

\begin{abstract}
Four cultures of photosynthetic bacteria isolated from poultry slaughterhouse wastewater were identified as Rhodocyclus gelatinosus based on the following properties: reddish color of cultures in synthetic medium, presence of motility, slightly curved Gram-negative rods morphology, gelatin liquefying activity, utilization of citrate as carbon source and production of bacteriochlorophyl a and carotenoids of the spirilloxanthin alternative series. R. gelatinosus may represent a source of nutrients and pigments with application in poultry feed.
\end{abstract}

Key words: Photosynthetic bacteria, Rhodocyclus gelatinosus, poultry slaughterhouse wastewater

\section{INTRODUCTION}

Purple non-sulfur bacteria (PNSB) are among the most energetically versatile of all prokaryotes. These phototrophic bacteria have the ability to utilize various organic compounds as substrates to carry out their photoheterotrophic metabolism under anaerobiosis in the presence of light and to grow photoautotrophically using $\mathrm{CO}_{2}$ as carbon source and either sulfur reduced compounds or $\mathrm{H}_{2}$ as electron donors. Some PNSB can also grow anaerobically in the dark using fermentative metabolism but most can grow aerobically in darkness by respiration (Brock et al., 1994). They represent a very heterogeneous group, with different types of metabolism, morphology, composition of photosynthetic pigments and internal membrane structures (Balloni et al., 1982; Imhoff and Trüper, 1989; Brock et al.,
1994). Members of this group are widely distributed in nature. They may be found in aquatic environments, either marine or freshwater and in moist soils (Imhoff and Trüper, 1989) and are also associated with many kinds of industrial wastewaters, where they play an important role in the decontamination of pollutants, mainly under sunlight and in sub-surface environments, where anaerobic conditions prevail (Kobayashi and Tchan, 1973; Kobayashi, 1975; Pfennig, 1978; Siefert et al., 1978; Sasikala et al., 1995). Many authors have suggested the use of PNSB for the depuration of industrial wastewaters, with the advantage of biomass production, known to be rich in compounds such as proteins with high amounts of essential amino acids, carotenoids, biological cofactors and vitamins, specially $\mathrm{B}_{12}$ (Kobayashi, 1975; Kobayashi and Kurata, 1978; Noparatnaraporn et al., 1983; Balloni et al., 1986;

\footnotetext{
* Author for correspondence
} 
Balloni et al., 1987). The purpose of this study was to develop a methodology for the isolation of Rhodocyclus gelatinosus from poultry slaughterhouse wastewater and for its characterization.

\section{MATERIALS AND METHODS}

Poultry slaughterhouse wastewater: Wastewater generated from poultry slaughter and rinsing, after filtering, decantation and flotation operations was collected in plastic bottles previously disinfected with $100 \mathrm{ppm}$ sodium hypocloride solution and taken to laboratory under anaerobiosis by tight closing of the bottles.

Reference microbial culture: Rhodocyclus gelatinosus wild type strain 52 used as reference for the identification experiments was donated by Centre de Génétique Moléculaire, Gif sur Yvette, France (Jirsakova and Reiss-Husson, 1993).

Culture media: Pfennig's medium (Pfennig, 1974) containing (g/l) $\mathrm{KH}_{2} \mathrm{PO}_{4} 0.5 ; \mathrm{MgSO}_{4} .7 \mathrm{H}_{2} \mathrm{O}$ 0.4; $\mathrm{NaCl} 0.4 ; \quad \mathrm{NH}_{4} \mathrm{Cl} 0.4 ; \mathrm{CaCl}_{2} .2 \mathrm{H}_{2} \mathrm{O} \quad 0.05$; organic compound 1 ; yeast extract 0.2 ; ferric citrate 0.005 ; trace elements solution $10 \mathrm{ml}$ $\left(\mathrm{FeSO}_{4} .7 \mathrm{H}_{2} \mathrm{O} \quad 200 \mathrm{mg} ; \mathrm{ZnSO}_{4} .7 \mathrm{H}_{2} \mathrm{O} \quad 10 \mathrm{mg}\right.$; $\mathrm{MnCl}_{2} .4 \mathrm{H}_{2} \mathrm{O} 3 \mathrm{mg} ; \mathrm{H}_{3} \mathrm{BO}_{3} 30 \mathrm{mg} ; \mathrm{CoCl}_{2} \cdot 6 \mathrm{H}_{2} \mathrm{O} 20$ $\mathrm{mg} ; \mathrm{CuCl}_{2} \cdot 2 \mathrm{H}_{2} \mathrm{O} 1 \mathrm{mg} ; \mathrm{NiCl}_{2} \cdot 6 \mathrm{H}_{2} \mathrm{O} 2 \mathrm{mg}$; $\mathrm{Na}_{2} \mathrm{MoO}_{4} \cdot 2 \mathrm{H}_{2} \mathrm{O} 3 \mathrm{mg}$ ) was used (pH 7.0). It was autoclaved at $121^{\circ} \mathrm{C}$ for 15 minutes. Nutritivegelatin agar (Koneman et al., 1989) contained (g/l) meat extract 3; bacteriological peptone 20; gelatin 120 , and was autoclaved at $121^{\circ} \mathrm{C}$ for 15 minutes (pH 6.8). Motility agar (Bier, 1978) contained $(\mathrm{g} / \mathrm{l})$ bacteriological peptone 10 ; yeast extract 3; $\mathrm{NaCl} 5$; gelatin 80 ; bacteriological agar 4 , and was autoclaved at $121^{\circ} \mathrm{C}$ for 15 minutes ( $\mathrm{pH} 7.4)$.

Vitamin solutions: Biotin $0.0015 \%$ sol.: biotin $1.5 \mathrm{mg}$; distilled water $100 \mathrm{ml}$. Membrane filtration on Millipore ${ }^{\mathrm{TM}} 0.22 \mu \mathrm{m}$. Thiamine $0.005 \%$ sol.: thiamine- $\mathrm{HCl} 5 \mathrm{mg}$; distilled water $100 \mathrm{ml}$. Membrane filtration on Millipore ${ }^{\mathrm{TM}} 0.22$ $\mu \mathrm{m}$.

Isolation of Rhodocyclus gelatinosus: Waste samples were filtered three times (once through a metal sieve and twice through paper filter Whatman $^{\mathrm{TM}}$ \# 3) and left under anaerobiosis in $500 \mathrm{ml}$ glass cylinders supplied with glass stoppers for 7 days at $32 \pm 2{ }^{\circ} \mathrm{C}$ and light intensity of $1400 \pm 200$ lux, generated by incandescent $(40 \mathrm{~W})$ and fluorescent $(15 \mathrm{~W})$ lamps in an oven. After that, waste was transferred $(30 \% \mathrm{v} / \mathrm{v})$ to screw-cap test tubes $(15 \times 180 \mathrm{~mm})$ completely filled with Pfennig's medium (sodium acetate as organic compound). Tubes were tightly closed to keep anaerobiosis atmosphere and incubated as above. Contents of these tubes were transferred $(30 \% \mathrm{v} / \mathrm{v})$ to new screw-cap test tubes and filled with Pfennig's medium (sodium acetate as organic compound) enriched with biotin $0.0015 \%$ $(1 \mathrm{ml} / \mathrm{l})$ and thiamine $0.005 \%(1 \mathrm{ml} / \mathrm{l})$ instead of yeast extract. Vitamin solutions were added after medium autoclaving. Incubation conditions were the same used previously. Enriched cultures were purified by repeated streaking on agar plates (Pfennig's medium enriched with vitamin solutions plus $2 \%$ bacteriological agar) until colonies were obtained. Plate dishes were kept in glass jars where anaerobiosis atmosphere was produced with $\mathrm{CO}_{2}$ (Anaerobac ${ }^{\mathrm{TM}} /$ Probac) and incubated at $32 \pm 2^{\circ} \mathrm{C}$ and $1400 \pm 200$ lux for 10 days.

Identification of $\boldsymbol{R}$ gelatinosus: Each pink or red colony isolated from petri dishes, as well as wild type strain 52 maintained in Pfennig's semi-solid agar (Pfennig's medium plus 1.2\% bacteriological agar), were suspended in sterile saline and submitted to the following characterization tests, which were performed in triplicates:

Gelatin hydrolysis. Suspensions were transferred to screw-cap test tubes completely filled with nutritive-gelatin agar and incubated under anaerobiosis, at $32 \pm 2^{\circ} \mathrm{C}$ and $1400 \pm 200 \mathrm{lux}$, during 15 to 20 days.

Motility. Suspensions were transferred to screwcap test tubes containing motility agar and incubated under anaerobiosis, at $32 \pm 2{ }^{\circ} \mathrm{C}$ and $1400 \pm 200$ lux, during 7 to 10 days.

Morphology. Morphology was checked through optical microscopy of Gram-stained suspensions (Bier, 1978).

Citrate utilization. Suspensions were transferred to screw-cap test tubes completely filled with liquid Pfennig's medium containing ferric citrate as sole organic compound and incubated under 
anaerobiosis, at $32 \pm 2^{\circ} \mathrm{C}$ and $1400 \pm 200$ lux, during 15 to 20 days.

Absorption spectrum of living cells. One loop of each of the four cultures identified as $R$. gelatinosus on the basis of tests as above, as well as of the wild type strain 52 were transferred to screw-cap test tubes filled with Pfennig's medium enriched with $0.3 \%$ yeast extract. After 10 days of incubation under anaerobiosis at $1400 \pm 200$ lux and $32 \pm 2{ }^{\circ} \mathrm{C}, 3.5 \mathrm{ml}$ of each culture were homogenized with $5 \mathrm{~g}$ of sucrose and the absorption spectrum was measured in a Varian 634 spectrophotometer using Pfennig's medium enriched with $0.3 \%$ yeast extract as the blank (Silva, 1997).

\section{RESULTS AND DISCUSSION}

Bergey's Manual of Determinative Bacteriology (Holt et al., 1994) describes the existence of six genera and 26 species in subgroup 3 of the classification of anoxigenic phototrophic bacteria. Among them, Rhodocyclus gelatinosus is characterized as a slightly curved and motile rod that may use a variety of carbon compounds as electron and carbon sources under anaerobic conditions in the light. This microorganism requires biotin and thiamine as growth factors, produces carotenoid pigments of the alternative spirilloxanthin series and is able to hydrolyze gelatin and to utilize citrate as sole carbon source. These features differ this species from the others of the genus (Imhoff and Trüper, 1989; Willens et al., 1991; Holt et al., 1994; Sasikala et al., 1995). According to Imhoff and Trüper (1989), the description of cell morphology, color of the cell suspensions, in vivo absorption spectra and some physiological properties leads to the identification of most species of PNSB.

From characteristics presented in Table 1, four cultures $\left(\mathrm{R}_{1}, \mathrm{R}_{2}, \mathrm{R}_{3}, \mathrm{R}_{4}\right)$ were identified as Rhodocyclus gelatinosus as compared to Rhodocyclus gelatinosus wild type strain 52 . These features agreed with those described for $R$. gelatinosus in the literature (Balloni et al. 1982; Imhoff and Trüper, 1989; Prasertsan et al., 1993; Holt et al., 1994). On both liquid and solid Pfennig's media, cultures showed red color after incubation period due to interaction among peculiar photosynthetic pigments of Rhodocyclus gelatinosus. Microbial growth occurred along the whole test tubes with liquid medium because these bacteria showed positive-phototaxy and were able to adhere to glassware where they became immobilized because of their flagella interlace and because of the abundant mucus production on liquid media, typical for this organism (Balloni et al., 1982). Slightly curved and rod-shaped morphology, as well as Gramnegative staining and presence of motility were in agreement with literature data (Balloni et al., 1982; Imhoff and Trüper, 1989; Prasertsan et al., 1993). Motility was confirmed by the presence of growth around needle puncture in motility agar. In young cultures, cells of $R$. gelatinosus are highly motile by means of polar flagella (Imhoff and Trüper, 1989).

Table 1 - Characteristics of $R$. gelatinosus cultures

\begin{tabular}{|c|c|c|c|c|c|}
\hline \multirow[b]{2}{*}{ Characteristic } & \multicolumn{5}{|c|}{ R. gelatinosus } \\
\hline & $\mathrm{R}_{1}$ & $\mathrm{R}_{2}$ & $\mathrm{R}_{3}$ & $\mathrm{R}_{4}$ & strain 52 \\
\hline \multicolumn{6}{|l|}{ Color of culture } \\
\hline $\begin{array}{l}\text { (synthetic } \\
\text { media) }\end{array}$ & + & + & + & & + \\
\hline \multirow{2}{*}{\multicolumn{6}{|c|}{$\begin{array}{c}\text { red } \\
\text { Cell shape }\end{array}$}} \\
\hline & & & & & \\
\hline curved rods & + & + & + & & + \\
\hline \multicolumn{6}{|l|}{ Gram staining } \\
\hline Gram (-) & + & + & + & & + \\
\hline Motility & + & + & + & & + \\
\hline Citrate utilized & + & + & + & & + \\
\hline Gelatin utilized & + & + & + & & + \\
\hline
\end{tabular}

Cultures classified as positive-gelatinase appeared deep red after incubation period and showed liquefaction of gelatin agar after 30 minutes at $4^{\circ} \mathrm{C}$. The main feature of this organism was the ability to liquefy gelatin by means of an extracellular protease activity (Imhoff and Trüper, 1989; Holt et al., 1994). The four cultures grew slowly in Pfennig's medium containing citrate and only developed pink to red color after near 15 days of incubation. $R$. gelatinosus produces citrate lyase, which enables it to consume citrate 
and excrete large amounts of acetate to the medium, serving as carbon source after citrate comes exhausted (Imhoff and Trüper, 1989; Holt et al., 1994). Photosynthetic pigments produced by $R$. gelatinosus were bacteriochlorophyl $a$ and carotenoids of the alternative spirilloxanthin series, with spheroidene, hydroxispheroidene and spirilloxanthin as major compounds (Holt et al., 1994). In vivo absorption spectra for the four isolated strains and for the wild type strain 52 are showed in Fig. 1 and their absorption maxima are showed in Table 2. According to Trüper and Imhoff (1992), absorption maxima of $R$. gelatinosus cell suspensions are 373-374, 455$460,476-486,506-518,806-810$ and $854-865 \mathrm{~nm}$, due to the blend of alternative spirilloxanthin series carotenoids and bacteriochlorophyl $a$, whose absorption maxima

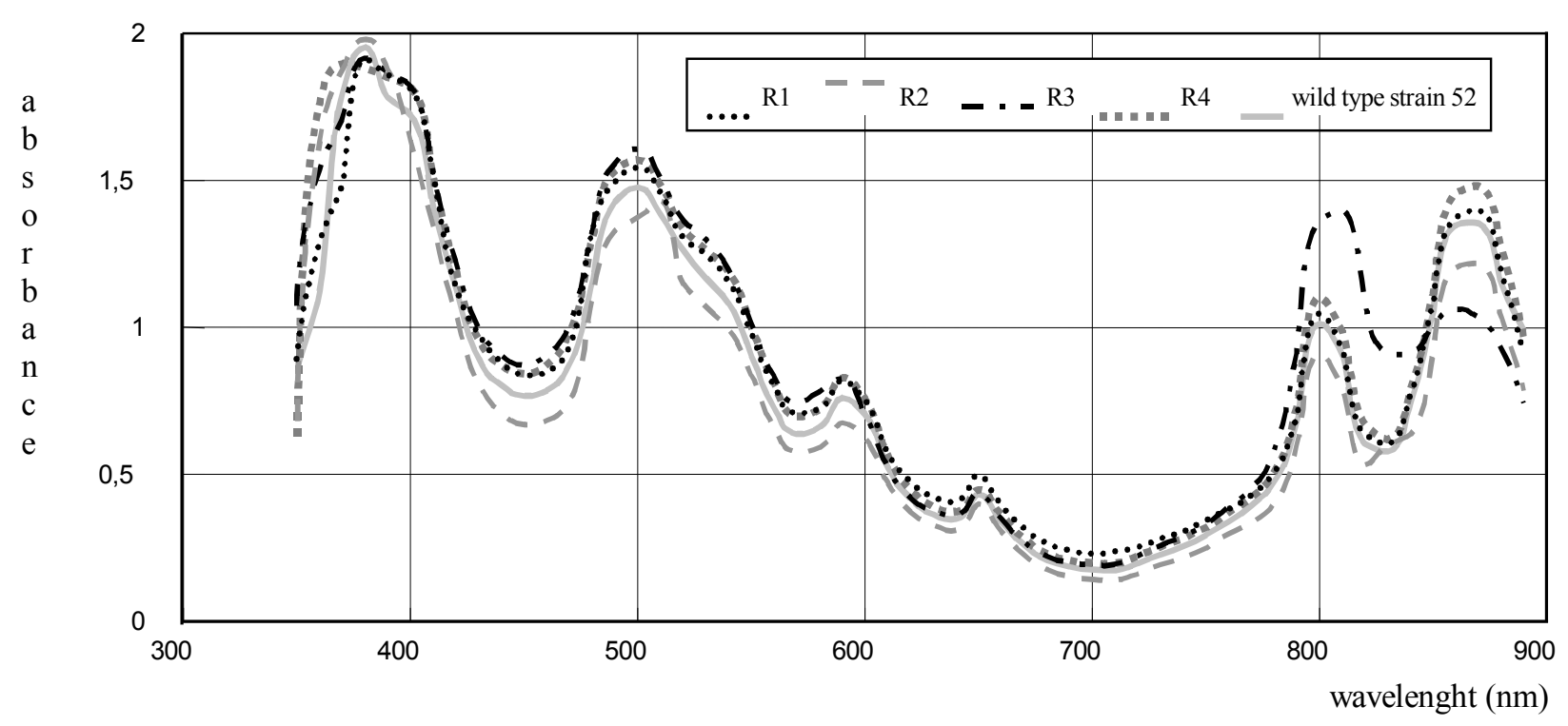

Figure 1 - Absorption spectra of living cells of $R$. gelatinosus $\left(\mathrm{R}_{1}, \mathrm{R}_{2}, \mathrm{R}_{3}, \mathrm{R}_{4}\right.$ and strain 52$)$

are at $375,590,800-810$ and $830-890 \mathrm{~nm}$ (Imhoff and Trüper, 1989; Brock et al., 1994). These peaks are in agreement with those found to $\mathrm{R}_{1}, \mathrm{R}_{2}, \mathrm{R}_{3}, \mathrm{R}_{4}$ and to wild type strain 52 , used for comparison.

Table 2 - In vivo absorption maxima of $R$. gelatinosus

\begin{tabular}{cc}
\hline Culture & $\lambda(\mathrm{nm})$ \\
\hline $\mathrm{R}_{1}$ & $375,460,500,590,650,800,865$ \\
$\mathrm{R}_{2}$ & $380,455,500,590,650,800,865$ \\
$\mathrm{R}_{3}$ & $380,455,500,590,650,805,860$ \\
$\mathrm{R}_{4}$ & $375,460,500,590,650,805,865$ \\
strain 52 & $375,460,500,590,650,800,865$ \\
\hline
\end{tabular}

Based on the results found in this experiment about color of cultures, cells morphology and motility, gelatin liquefaction, citrate utilization and absorption spectrum, four cultures $\left(\mathrm{R}_{1}, \mathrm{R}_{2}\right.$, $\mathrm{R}_{3}, \mathrm{R}_{4}$ ) isolated from poultry slaughterhouse wastewater were identified as Rhodocyclus gelatinosus, as compared to a reference $R$. gelatinosus strain.

\section{ACKNOWLEDGMENTS}

E. H. G. P. thanks Alberto Minoru Miyasaka and Frango Sertanejo staff for the cooperation and the supply of the waste.

\section{RESUMO}

Quatro culturas de bactérias fotossintetizantes isoladas de águas residuárias de abatedouro de aves foram identificadas como Rhodocyclus gelatinosus com base nas seguintes propriedades: desenvolvimento de cor avermelhada nos cultivos 
em meio sintético, motilidade positiva, morfologia de bastonetes gram-negativos ligeiramente curvos, atividade de liquefação da gelatina, utilização de citrato como fonte de carbono e produção de bacterioclorofila $a$ e carotenóides da série espiriloxantina alternativa. Esses testes foram também aplicados para uma linhagem de Rhodocyclus gelatinosus de referência para efeito de comparação. A biomassa de $R$. gelatinosus pode representar uma fonte de nutrientes e de pigmentos na alimentação de aves.

\section{REFERENCES}

Balloni, W.; Materassi, R.; Filpi, C.; Sili, C.; Vicenzini, M.; Ena, A. and Florenzano, G. (1982), Il metodo di trattamento a batteri fotosintetici delle acque di scarico. Quaderno AQ/2/21. Centro de Studio del Microrganismi Autotrofi, Firenze.

Balloni, W.; Carlozzi, P.; Ventura, S. and Sacchi, A. (1986), Microbial biomass for fertilizer use from the photo-anaerobic treatment of pig-wastes. In: Symposium on Compost, 17-19 April, Udine.

Balloni, W.; Carlozzi, P.; Ventura, S.; De Philippis, R. and Bosco, M. (1987), A three years experiment on the production of Rhodopseudomonas and Rhodospirillum biomass by outdoor culture on different wastes. $4^{\text {th }}$ In: Conference on Biomass for Energy and Industry, 11-15 May, Orleans.

Bier, O. (1978), Bacteriologia e Imunologia. São Paulo : Melhoramentos.

Brock, T. D.; Madigan, M. T.; Martinko, J. M. and Parker, J. (1994), Biology of microorganisms. New York : Prentice Hall.

Holt, J. G.; Bergey, D. H.; Krieg, N. R.; Sneath, P. H. A. and Williams, S. T. (1994), Anoxygenic phototrophic bacteria. In: Bergey's Manual of Determinative Bacteriology. Williams and Wilkins, Baltimore. pp. 353-376.

Imhoff, J. P. and Trüper, H. G. (1989), Purple nonsulfur bacteria. In: Bergey's Manual of Systematic Bacteriology. Williams and Wilkins, Baltimore. pp. 1635-1709.

Jirsakova, V. and Reiss-Husson, F. (1993), Isolation and characterization of the core light-harvesting complex B875 and its subunit form, B820, from Rhodocyclus gelatinosus. Biochim. Biophys. Acta., 11, 301-308.

Kobayashi, M. (1975), Role of photosynthetic bacteria in foul water purification. Prog. Water Technol., 7, 309-315.

Kobayashi, M. and Tchan, Y. T. (1973), Treatment of industrial waste solutions and production of useful by- products using a photosynthetic bacterial method. Water Res., 7, 1219-1224.

Kobayashi, M. and Kurata, S. (1978), The mass culture and cell utilization of photosynthetic bacteria. Process Biochem., 7., 27-30.

Koneman, E. W.; Allen, S. D.; Dowell, Jr, V. R. and Sommers, H. M. (1989), Diagnóstico microbiológico. Panamericana, São Paulo.

Noparatnaraporn, N.; Nishizawa, Y.; Hayashi, M. and Nagai, S. (1983), Single cell protein production from cassava starch by Rhodopseudomonas gelatinosa. J. Ferment. Technol., 61, 515-519.

Pfennig, N. (1974), Rhodopseudomonas globiformis, sp. n., a new species of the Rhodospirillaceae. Arch. Microbiol., 100, 197-206.

Pfennig, N. (1978), Rhodocyclus purpureus gen. nov. and sp. nov., a ring-shaped vitamin $\mathrm{B}_{12}$-requiring member of the family Rhodospirillaceae. In: J. Syst. Bacteriol., 28, 283-288.

Prasertsan, P.; Choorit, W. and Suwanno, S. (1993), Isolation, identification and growth conditions of photosynthetic bacteria found in seafood processing wastewater. World J. Microbiol. Biotechnol., 9, 590-592.

Sasikala, C.; Ramana, C. V.; Chalam, A. V.; Jayasri, K. and Raghuveer Rao, P. (1995), A survey of purple non-sulfur anoxygenic phototrophic bacteria associated with some industrial effluents. Indian $J$. Exp. Biol., 33, 136-138.

Siefert, E.; Irgens, R. L. and Pfennig, N. (1978), Phototrophic purple and green bacteria in a sewage treatment plant. Appl. Environ. Microbiol., 35, 38-44.

Silva, E. M. (1997), Tratamento das águas residuárias do abatedouro avícola por bactérias fotossintetizantes. Ph.D. Thesis, Bioscience Institute. Rio Claro : UNESP.

Trüper, H. G. and Imhoff, J. F. (1992), The genera Rhodocyclus and Rubrivivax. In: Balows, A. et al. (eds.). The prokaryotes. Spring-Verlag, Berlin, 2, 2556-2561.

Willens, A.; Gillis, M. and De Ley, J. (1991), Transfer of Rhodocyclus gelatinosus to Rubrivivax gelatinosus gen. nov., comb. nov., and phylogenetic relationships with Leptothrix, Sphaerotilus natans, Pseudomonas saccharophila and Alcaligenes latus. In: J. Syst. Bacteriol., 41, 65-73.

Received: February 15, 2001; Revised: September 19, 2001; Accepted: November 27, 2001. 